\title{
The Morphological and Functional Organization of Cattails Typha laxmannii Lepech. and Typha australis Schum. and Thonn. under Soil Pollution by Potentially Toxic Elements
}

\author{
Tatiana Minkina ${ }^{1}\left(\mathbb{D}\right.$, Grigoriy Fedorenko ${ }^{1,2}$, Dina Nevidomskaya ${ }^{1, *} \mathbb{D}$, Elizaveta Konstantinova ${ }^{1}(\mathbb{D}$, \\ Tatiana Pol'shina ${ }^{2}$, Aleksei Fedorenko ${ }^{1,2}{ }^{1}$, Victor Chaplygin ${ }^{1}$, Saglara Mandzhieva ${ }^{1}$, Tamara Dudnikova ${ }^{1}$ \\ and Tara Hassan ${ }^{1}$ \\ 1 Southern Federal University, 344006 Rostov-on-Don, Russia; tminkina@mail.ru (T.M.); \\ gfedorenko@mail.ru (G.F.); konstantliza@gmail.com (E.K.); afedorenko@mail.ru (A.F.); \\ otshelnic87.ru@mail.ru (V.C.); msaglara@mail.ru (S.M.); tyto98@yandex.ru (T.D.); \\ tara.hassan@su.edu.krd (T.H.) \\ 2 Federal Research Center the Southern Scientific Center of the Russian Academy of Sciences, \\ 344006 Rostov-on-Don, Russia; tanja0701@mail.ru \\ * Correspondence: dnevidomskaya@mail.ru; Tel.: +7-918-553-1632
}

check for updates

Citation: Minkina, T.; Fedorenko, G.; Nevidomskaya, D.; Konstantinova, E.; Pol'shina, T.; Fedorenko, A.; Chaplygin, V.; Mandzhieva, S.; Dudnikova, T.; Hassan, T. The Morphological and Functional Organization of Cattails Typha laxmannii Lepech. and Typha australis Schum. and Thonn. under Soil Pollution by Potentially Toxic Elements. Water 2021, 13, 227. https: / doi.org/10.3390/w13020227

Received: 10 December 2020

Accepted: 14 January 2021

Published: 18 January 2021

Publisher's Note: MDPI stays neutral with regard to jurisdictional claims in published maps and institutional affiliations.

Copyright: (c) 2021 by the authors. Licensee MDPI, Basel, Switzerland. This article is an open access article distributed under the terms and conditions of the Creative Commons Attribution (CC BY) license (https:/ / creativecommons.org/licenses/by/ $4.0 /)$.

\begin{abstract}
The aim of this study is to investigate the adaptation of two species of cattail Typha australis Schum. and Thonn. and Typha laxmannii Lepech. based on analysis of the morphological and anatomical features of their vegetative and generative organs to soil pollution with potentially toxic elements (PTE) in the riparian zones of the sea edge of the Don River delta (Southern Russia). Both species of the cattail are able to accumulate high concentrations of $\mathrm{Ni}, \mathrm{Zn}, \mathrm{Cd}, \mathrm{Pb}$ and can be used for phytoremediation of polluted territories. The pattern of PTE accumulation in hydrophytes has changed on polluted soils of coastal areas from roots/rhizomes $>$ inflorescences $>$ stems to roots/rhizomes $>$ stems $\geq$ inflorescences. The comparative morphological and anatomical analysis showed a statistically significant effect of the environmental stress factor by the type of proliferation in T. australis, and species T. laxmannii was visually in a depressed, deformed state with mass manifestations of hypogenesis. These deformations should be considered, on one hand, as adaptive, but on the other, as pathological changes in the structure of the spikes of the cattails. Light-optical and electron microscopic studies have shown that the degree and nature of ultrastructural changes in cattails at the same level of soil pollution are different and most expressed in the assimilation tissue of leaves. However, these changes were destructive for T. australis, but for T. laxmannii, these indicated a high level of adaptation to the prolonged technogenic impact of PTE.
\end{abstract}

Keywords: fluvisols; potentially toxic elements; hydrophytes; bioaccumulation; riparian zone; adaptation; morphological features; anatomical features; ultrastructure

\section{Introduction}

The sea routes development strategy always affects the coastal territories with the active developing transport, commercial, recreational, and other industries by increasing anthropogenic impact on the environment [1-5]. The ecosystems are facing increasing anthropogenic and environmental pressure. Well-known stressors are potential toxic elements (PTE), especially heavy metals ( $\mathrm{Cr}, \mathrm{Ni}, \mathrm{Cu}, \mathrm{Zn}, \mathrm{Pb}, \mathrm{Cd}, \mathrm{Mn}$ and others) [6]. The most important interfaces involved in the adsorption of PTE to soils are inorganic colloids such as clays, Fe and Mn oxides and hydroxides, carbonates and phosphates [7,8]. Such edaphic factors like sorptive capacity of the soil, cation exchange capacity, soil $\mathrm{pH}$, and organic matter content affect PTE accumulation in plants [9]. High concentrations of PTE are toxic for living organisms and are objects for constant environmental monitoring. The significance of coastal vegetation in the riparian ecosystems is hard to overstate. They are 
important for oxygen production, nutrient cycles, water quality control and sediment stabilization [10]. The study of the mechanisms of resistance of coastal-aquatic vegetation, including hydrophytes, to pollution of aquatic ecosystems at the land-sea margin is becoming increasingly important. It has been noted that the Typhaceae family can grow in habitats with high PTE levels [11-19]. PTE take-up is a very complicated process, including element uptake from soil solution to inside cells of roots [20]. Hydrophytes are very adaptive to changing habitats due to the fast transformation of metabolic processes [16-18]. This ability can be used to determine the ecological plasticity of plants in conditions of toxic impact with different action mechanisms. However, the cellular mechanisms regulating the adaptive capabilities of aquatic plants to unfavorable environmental conditions, including at the ultrastructural level, are still weakly studied [21-23].

Typha is the primary producer of estuarine ecosystems, which has the ability to concentrate elements and compounds from the polluted soils and water bodies and to metabolize molecules in its tissues. Consequently, it can incorporate large amounts of elements from the environment [23]. Plant roots are mostly located in the soil; they can play a very crucial role in element removal via filtration, adsorption and cation exchange, and chemical changes that take place in the rhizosphere through plant roots [24-26]. High concentrations of PTEs in Typha can be accumulated from the water column and from soils demonstrating the usefulness of Typha plants as biomonitors for estuarine systems [27]. Bioaccumulation of PTE by the plants in changing environmental conditions results in transformations at the morphological and cellular levels providing the resistance and possible adaptation of the plants to various ecological conditions [14,15,28-31].

To shield themselves from the toxic effect of PTE, Typha plants must form mechanisms by which the elements entering the cytosol are either excluded immediately or complexed and neutralized or binding to the cell walls and eventually to root exudates [32,33], reduced influx through the plasma membrane, chelation in the cytosol by various ligands such as phytochelatins and metallothioneins and further PTE compartmentalization in the vacuole [34]. When roots take up PTE ions, they are either stored in roots or shipped to the shoot. Along these lines, micronutrient take-up systems are of great interest to phytoremediation [31,35].

The aim of the present study was to analyze the morphological and anatomical features of the adaptation of two species of cattail Typha australis Schum. and Thonn. and Typha laxmannii Lepech. under PTE pollution of soils in the riparian zones of the sea edge of the Don River delta (Southern Russia).

\section{Materials and Methods}

\subsection{Study Area}

The Don River has an extended basin of about 422 thousand $\mathrm{km}^{2}$, and numerous liquid and solid wastewaters fall directly into the reservoirs. The Don River delta extends to $538 \mathrm{~km}^{2}$ and begins $6 \mathrm{~km}$ below Rostov-on-Don-the largest city in the South of Russia. The Don River delta is an accumulative formation with numerous channel watercourses flowing into the Taganrog Bay of the Azov Sea. According to geomorphological characteristics, the Don River delta belongs to the island type with a shallow seashore. The upper delta is located at a branch node from the Don River of the Mertvy Donets branch-a shallow, relatively narrow and long channel. The delta frontiers from the north and south are the primary shores of the Don River valley, and Taganrog Bay from the west [36]. The Don River delta has great economic importance. There are Azov seaports, about 30 port terminals, a fish processing plant, a ship-repairing yard, several fish farms and other enterprises located here. The delta is densely populated and includes many settlements. Water transport plays an essential role. In addition, the delta is used for vegetable gardens, cereal crops, hayfields, and pastures. The cities of Rostov-on-Don, Novocherkassk, Azov, Bataisk, with large industrial enterprises emitting large volumes of pollutants into the atmosphere and the hydrosphere, are also located on the border of the Don River delta or within it. West and southwest winds create conditions for high water rises in the delta. 
Water overflows the banks when the height of the river-bed banks is exceeded; as a result, significant areas of the Don delta and floodplain.

The study was carried out in the coastal zone of the Don River delta at four monitoring plots, different in the prevailing plant species and the intensity of anthropogenic impact (Figure 1). Polluted plots $8 \mathrm{~K}\left(47^{\circ} 03^{\prime} 04^{\prime \prime} \mathrm{N}, 39^{\circ} 18^{\prime} 22^{\prime \prime} \mathrm{E}\right)$ and $\mathrm{T} 4\left(47.071433^{\circ} \mathrm{N}, 39.313392^{\circ} \mathrm{E}\right)$ are located in the vicinity of the village of Kagalnik; the predominant species are T. australis and T. laxmannii, respectively. Background plots $5 \mathrm{~K}\left(47^{\circ} 07^{\prime} 27^{\prime \prime} \mathrm{N}, 39^{\circ} 14^{\prime} 45^{\prime \prime} \mathrm{E}\right)$ and T1 $\left(47^{\circ} 04^{\prime} 18^{\prime \prime} \mathrm{N}, 39^{\circ} 18^{\prime} 48^{\prime \prime} \mathrm{E}\right)$ are located on the territory of a specially protected natural area Donskoy Nature Park; cattails are represented by T. australis and T. laxmannii, respectively. The natural park's functioning provides territorial protection for well-preserved typical communities of the lower reaches of the Don River, which can serve as standards of the natural soil cover of the river floodplains of the steppe zone. The soil cover in the Don River delta area is represented by hydromorphic fluvisols [37].

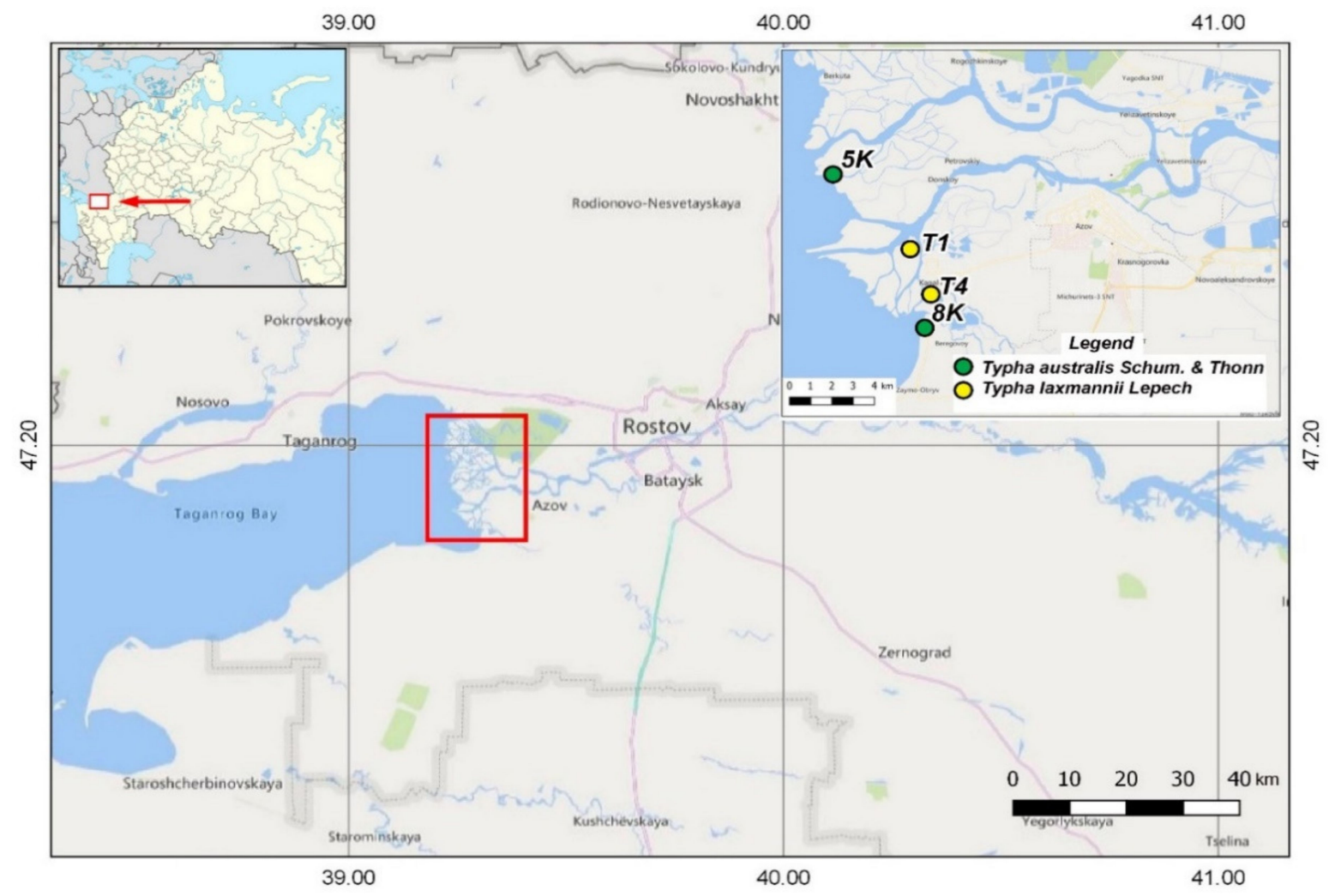

Figure 1. The sea edge of the Don River delta, showing the sampling locations for soils and plants: background plots: $5 \mathrm{~K}$ and T1, polluted plots: $8 \mathrm{~K}$ and $\mathrm{T} 4$.

\subsection{Soil Sampling and Treatment}

At each monitoring plot with an area of $100 \mathrm{~m}^{2}$, mixed soil samples were collected using an envelope method from the surface soil horizon (depth 0-20 cm) [38]. The soil samples $(n=4)$ were air-dried, mixed, passed through a $2 \mathrm{~mm}$ sieve, and homogenized. The $\mathrm{pH}$ was determined by potentiometry in the supernatant suspension of soil and water in a ratio of 1:5 according to ISO 10390 [39]. Total organic carbon (Corg) content was determined by sulfochromic oxidation, the content of carbonates by the acid neutralization method, and the content of exchangeable cations by hexamminecobalt trichloride solution [40]. The soil samples were also analyzed for particle size distribution by the pipette method (using the pyrophosphate procedure of soil preparation) [41].

The total contents of $\mathrm{Cr}, \mathrm{Ni}, \mathrm{Cu}, \mathrm{Zn}, \mathrm{Pb}, \mathrm{Cd}$, and $\mathrm{Mn}$, in soil samples were determined by wavelength dispersive $\mathrm{X}$-ray fluorescence spectrometry (XRF) using a Spectroscan 
MAKS-GV spectrometer (Spectron, Russia). The XRF is one of the simplest, most accurate and most economic analytical methods for the determination of the chemical composition of many types of materials. Relative errors between 1 and $10 \%$ are typical for trace element analysis. Results obtained with XRF are highly correlated with results from atomic absorption spectrometry (AAC) but do not require labor and time-consuming sample digestion. XRF spectrometer could be employed to provide rapid in situ detection of the presence of toxic metals in soil samples [42,43]. The chemical analysis of each sample was conducted in triplicate relative to the control for analytical precision. The accuracy of metal content was verified with a reference standard state standard soil sample no. 9288-2009 (Federal State Unitary Enterprise Ural Research Institute of Metrology) to control measurement error methods of the total content of certified components in the soil and sediments. Duplicates and reagent blanks were also used as a part of quality control. The correctness of the obtained results was repeatedly confirmed by international intercalibrations.

Total pollution levels of PTEs in the soils of the monitoring plots in the coastal zone of the Don River delta were evaluated using an integral pollution index $\left(Z_{C}\right)[44,45]$, using for a comprehensive assessment of soil pollution by all of the elements studied. The equation as is follows:

$$
Z_{C}=\sum K_{c}-(n-1),
$$

where $n$ is the number of PTEs with $K_{C}>1$, and $K_{C}$ is the concentration coefficient, which was determined using the following formula:

$$
K_{c}=\frac{C_{i}}{C_{b}}
$$

where $C_{i}$ is the total content of metal $i$ in soil, and $C_{b}$ is the background value [15]. Four categories of soil pollution were defined according to $Z c$ values [46]: acceptable $(<16)$, moderately hazardous (16-32), hazardous (32-128), and extremely hazardous $(>128)$.

\subsection{Plant Sampling and Treatment}

Field observations and selection of plant samples for chemical and microscopic analysis were carried out in early July at each monitoring plot with an area of $100 \mathrm{~m}^{2}$. At each monitoring plot, 8-10 individuals of one predominant species of cattail were selected, from which mixed samples of roots, stems and inflorescence were formed to determine the content of PTEs (i.e., 4 plots $\times 1$ predominant species of cattail $\times 3$ mixed samples of different parts of cattails $=12$ plant samples). Fresh plants were carefully cleaned from soil and plant waste under running slack flow of distilled water prior to separation into parts. Then the obtained samples were cut into small pieces with a plastic knife, dried at room temperature until the constant weight and homogenized. The air-dried $1 \mathrm{~g}$ sample of plant tissues was oven-dried at $65^{\circ} \mathrm{C}$ and ashed in a muffle furnace at $450^{\circ} \mathrm{C}$ for $6 \mathrm{~h}$ [47]. The ash was dissolved in $5 \mathrm{~mL}$ of $20 \% \mathrm{HCl}$ and filtered through $0.45 \mathrm{~mL}$ Whatman filter paper, then washed into $50 \mathrm{~mL}$ flask and made volume using deionized water. PTEs in extracts were determined by atomic AAS. The AAS was calibrated daily using a standard solution. All analyses were carried out in triplicate, and results were expressed as the mean. Because the PTE content in plants is usually at the trace level, the use of AAS provides reliable outcomes due to the ability to reconcile high sensitivity and low limits of detection $[48,49]$.

Due to the using the Typha young shoots as feed for farm animals, the contents of PTEs in the studied plants were compared with the maximum permissible level (MPL) for chemical elements in forage for farm animals and feed additives [50].

At each monitoring site, the morphobiometric parameters of the generative organs of the dominant cattail species (T. australis or T. laxmannii) were measured on a sample of 50 plants so that morphobiometric characteristics were representative of each population of cattails. On monitoring plot, $8 \mathrm{~K}$, specimens of T. australis with deformations and a second spike on the axis of the inflorescence were observed. The following morphometric parameters were determined according to [51]: the shoot height, length and width of 
the spike, as well as the length and width of the second spike on the axis of the inflorescence in cattails with two spikes and the distance between the spikes.

\subsection{Procedure of Microscopic and Ultrastructural Analysis}

The preparation of samples for microscopy was carried out according to an original technique developed for preparation and double fixation of plant tissue of the fresh samples of cattails [31,52]. Cross-sections at the roots of cattails were made at a distance of 3 and $6 \mathrm{~cm}$ from the growth apex, and the choice of distances from the growth apex of the adventitious roots was arbitrary. Quantitative analysis included the calculation of the relative area $(\mathrm{P}, \%)$ of the trachea (Str) on the total cross-sectional area of soil roots (Scs) and the relative area $(\mathrm{P}, \%)$ of parenchyma (Sp) on the total cross-sectional area of leaves (Scs) of T. australis and T. laxmannii. Cross-sections for microscopic analysis were performed in ten replicates.

\subsection{Statistical Analysis}

The results of morphobiometric and microscopic analyses of studied plant specimens were statistically analyzed using STATISTICA 10.0. The normality of data was checked using the Shapiro-Wilk test. Descriptive statistics, including mean, median, minimum and maximum values, standard deviation (SD), and coefficients of variation $(\mathrm{CV})$, were calculated. Values obtained for different analyses were presented as mean $\pm \mathrm{SD}$. The datasets were subjected to factorial analysis of variance (ANOVA) for significant differences between groups $(p<0.05)$, fitting terms for plant species, level of pollution and interactions. If significant differences were identified at $p<0.05$, Tukey post hoc multiple comparisons test was applied in order to identify differences within the cattail species and plants populations within the polluted plots and the background.

\section{Results}

\subsection{The Contents and Distributions of PTE in Soils and Plants}

The studied soils had a weak-alkaline or alkaline reaction of the environment, and the Corg content was 1.6-1.9\%. Fluvisols were not saline, and the amount of dense residue was up to $0.15 \%$. The content of carbonates $\left(\mathrm{CaCO}_{3}\right)$ varied in the study areas from 1.8 to $3.4 \%$. The content of $\mathrm{CaCO}_{3}$ on the soil surface and significantly high amount of exchangeable $\mathrm{Ca}$ in the soil absorbing complex were associated with the presence of biogenic calcite in the washed horizons of fluvisols. The granulometric composition of all studied soils was sandy loamy (Table A1).

Monitoring plots affected by prolonged anthropogenic impact and confined to technogenic objects characterized by poly-element pollution several times exceeding the lithosphere clarke [53] and maximum permissible concentrations [54] by $\mathrm{Zn}, \mathrm{Cd}, \mathrm{Cu}$, and $\mathrm{Pb}$ (Table 1). The Cr content in fluvisols ranged from 210 to $307 \mathrm{mg} / \mathrm{kg}$ soil. According to the regional biogeochemical features of the elemental composition of soils and the mineralogical composition of pedogenic rocks of the Rostov region, $\mathrm{Cr}$ is the core of the background lithophilic association [55], a part of minerals or forms various oxides, and revealing an affinity with iron-containing soil phases. Pollution assessment of soils according to Zc value revealed that soils of monitoring plots $5 \mathrm{~K}$ and $1 \mathrm{~T}$ are characterized by an acceptable degree of pollution $(\mathrm{Zc}<16)$, therefore, these monitoring sites are considered as background (Table 1 ). The soils of monitoring plots $8 \mathrm{~K}$ and $4 \mathrm{~T}$ were affected by the long-term anthropogenic impact, which led to their poly-element pollution. The values of Zc in soils were 33.4 and 37.2, respectively, which indicates hazardous pollution of the territory [46]. 
Table 1. Total content of $\mathrm{Mn}, \mathrm{Cr}, \mathrm{Cu}, \mathrm{Zn}, \mathrm{Pb}, \mathrm{Cd}$ and $\mathrm{Ni}(\mathrm{mg} / \mathrm{kg})$ at the $0-20 \mathrm{~cm}$ layer of fluvisols at monitoring plots in the Don River delta.

\begin{tabular}{|c|c|c|c|c|c|c|c|c|c|}
\hline Monitoring Plot & Mn & $\mathrm{Cr}$ & $\mathrm{Cu}$ & $\mathrm{Zn}$ & $\mathrm{Pb}$ & Cd & $\mathbf{N i}$ & $\mathrm{Zc}$ & The Contamination Category \\
\hline 5K (background) & $1355 \pm 97$ & $244.0 \pm 17.1$ & $62.7 \pm 5.3$ & $\mathbf{1 0 4 . 9} \pm 8.1$ & $33.1 \pm 2.9$ & $0.28 \pm 0.01$ & $58.7 \pm 3.2$ & 11.2 & Acceptable \\
\hline 8K (polluted) & $1237 \pm 82$ & $297.0 \pm 23.4$ & $107.1 \pm 7.8$ & $691.0 \pm 55.2$ & $72.1 \pm 5.6$ & $\mathbf{0 . 6 7} \pm 0.01$ & $98.4 \pm 7.6$ & 33.4 & Hazardous \\
\hline T1 (background) & $955 \pm 61$ & $201.7 \pm 17.5$ & $71.3 \pm 5.6$ & $104.9 \pm 85.0$ & $42.5 \pm 3.7$ & $0.41 \pm 0.01$ & $69.5 \pm 7.4$ & 12.0 & Acceptable \\
\hline Lithosphere clarke [53] & 1000 & 83 & 47 & 83 & 16 & 0.13 & 58 & & \\
\hline $\begin{array}{l}\text { Maximum permissible } \\
\text { concentrations [54] }\end{array}$ & 1500 & 90 & 55 & 100 & 32 & 0.50 & 85 & & \\
\hline Background content [15] & $514 \pm 70$ & $71 \pm 9$ & $20 \pm 1.1$ & $40 \pm 3$ & $15 \pm 1$ & $0.3 \pm 0.02$ & $24 \pm 1.5$ & & \\
\hline
\end{tabular}

$\mathrm{Z}_{\mathrm{C}}$ is the integral pollution index. Exceedances of the lithosphere clarke and maximum permissible concentrations are typed in bold. 
The cattail plants were contaminated with PTEs such as $\mathrm{Ni}, \mathrm{Zn}, \mathrm{Cr}$ and $\mathrm{Pb}$ at plots under the anthropogenic impact (Table 2). The plants in the studied area were most exposed to $\mathrm{Ni}, \mathrm{Cr}$ and $\mathrm{Zn}$ pollution and to the least degree with $\mathrm{Pb}$. The plant samples of T. australis and T. laxmannii were characterized with an excess of the MPL [50]: Cr up to 19 times, $\mathrm{Zn}$ up to 4 times, Ni up to 4 times, and $\mathrm{Cd}$ up to 2 times. The excess of $\mathrm{Cr}$ in plant tissues, as noted above, is associated with the natural lithological specificity of this region [52]. The maximum concentration of $\mathrm{Zn}$ in cattails was observed in the roots and ranged from $174 \mathrm{mg} / \mathrm{kg}$ for T. australis to $195 \mathrm{mg} / \mathrm{kg}$ DW for T. laxmannii, exceeding its content in the vegetative and reproductive organs. The concentration of $\mathrm{Mn}$ and $\mathrm{Cu}$ in soils under cattail populations was lower than the threshold concentration.

\subsection{Morphometric Changes of T. australis and T. laxmannii}

By comparing the two species of cattails, it was noted that T. australis on polluted plots (plot $8 \mathrm{~K}$ ) formed a second spike that was not typical for this species and is an abnormal feature (Figure 2a-d). This feature could be a morphological manifestation of PTE toxicity.
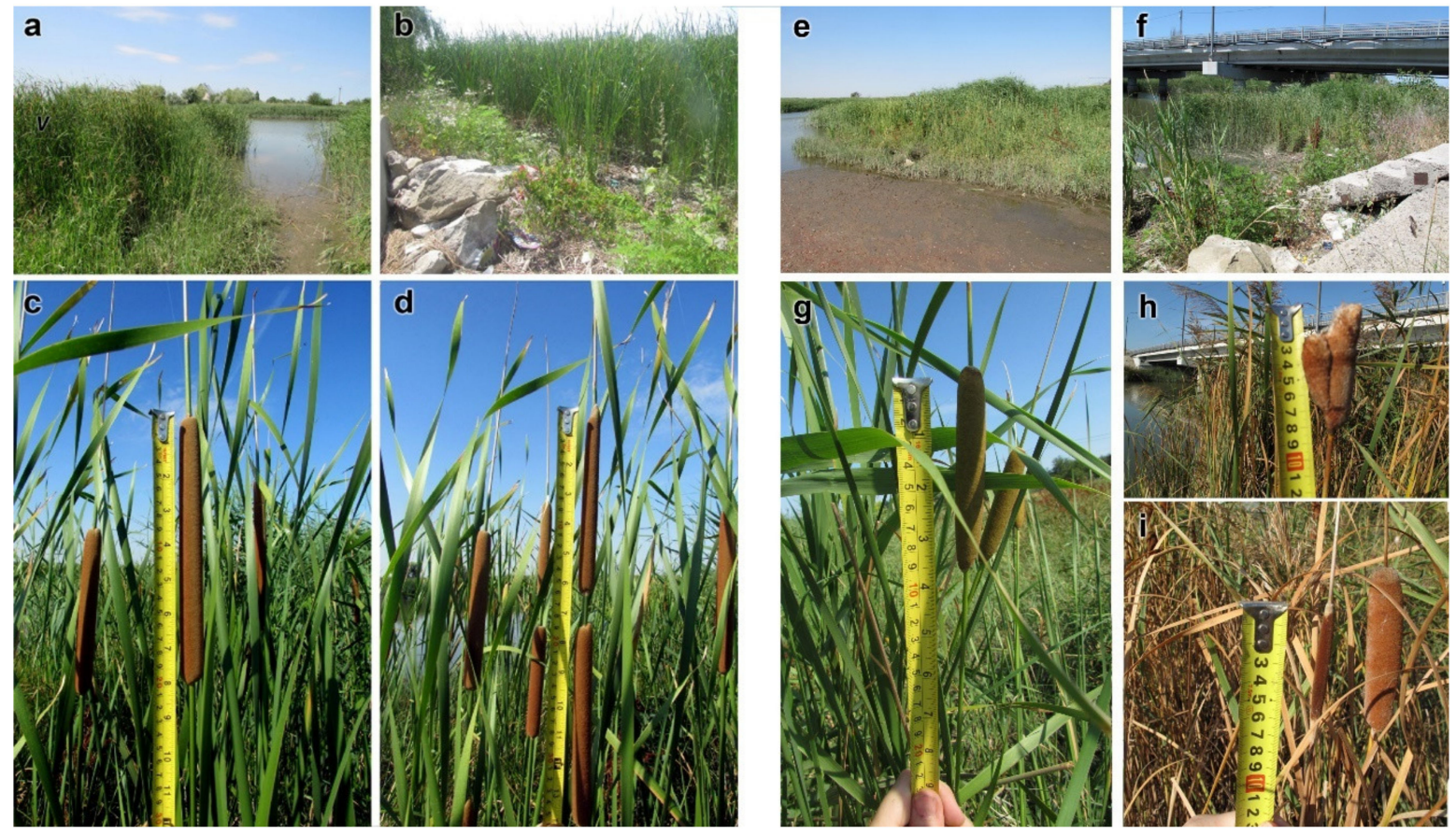

Figure 2. The general view of the monitoring plots and plants features; T. australis: (a) background plot (5K), (b) polluted plot (8K), (c) normal plant (plot 5K) and (d) plant with anomalies (plot 8K); T. laxmannii: (e) background plot (T1), (f) polluted plot (T4), (g) normal pistillate (plot T1); (h,i) deformed pistil spike (plot T4).

The results of ANOVA showed that the morphobiometric parameters of plants differ significantly $(p<0.05)$ depending on the plant species characteristics and growing conditions $(\mathrm{Zc})$, except for the spike diameter of cattail in the background and polluted plots (Table 3). 
Table 2. Content of $\mathrm{Mn}, \mathrm{Zn}, \mathrm{Cu}, \mathrm{Pb}, \mathrm{Cr}, \mathrm{Ni}$ and $\mathrm{Cd}(\mathrm{mg} / \mathrm{kg} \mathrm{DW})$ in plant parts of T. australis and T. laxmannii at the monitoring plots in the Don River delta.

\begin{tabular}{|c|c|c|c|c|c|c|c|c|c|}
\hline Monitoring Plot & Plant Species & Plant Part & Mn & Zn & $\mathrm{Cu}$ & $\mathrm{Pb}$ & $\mathrm{Cr}$ & $\mathbf{N i}$ & $\mathrm{Cd}$ \\
\hline \multirow{3}{*}{ 5K (background) } & \multirow{6}{*}{ T. australis } & Stem & $101 \pm 7$ & $17.5 \pm 1.4$ & $3.9 \pm 0.2$ & $0.6 \pm 0.1$ & $2.4 \pm 0.2$ & $1.1 \pm 0.1$ & $0.04 \pm 0.003$ \\
\hline & & Root & $144 \pm 9$ & $78.9 \pm 3.5$ & $9.9 \pm 0.7$ & $0.7 \pm 0.1$ & $4.5 \pm 0.3$ & $2.6 \pm 0.2$ & $0.06 \pm 0.007$ \\
\hline & & Inflorescence & $202 \pm 15$ & $\mathbf{6 2 . 6} \pm 4.3$ & $7.9 \pm 0.5$ & $1.0 \pm 0.2$ & $\mathbf{5 . 6} \pm 0.8$ & $1.4 \pm 0.1$ & $0.1 \pm 0.001$ \\
\hline \multirow{3}{*}{ 8K (polluted) } & & Stem & $118 \pm 9$ & $\mathbf{1 1 8 . 0} \pm 8.5$ & $14.4 \pm 0.1$ & $1.1 \pm 0.1$ & $7.6 \pm 0.5$ & $6.8 \pm 0.5$ & $\mathbf{0 . 6 1} \pm 0.01$ \\
\hline & & Root & $178 \pm 13$ & $\mathbf{1 7 4 . 1} \pm 13.6$ & $13.5 \pm 0.3$ & $6.5 \pm 0.3$ & $9.7 \pm 0.6$ & $\mathbf{9 . 3} \pm 0.5$ & $\mathbf{0 . 7 3} \pm 0.02$ \\
\hline & & Inflorescence & $357 \pm 26$ & $98.0 \pm 7.6$ & $8.8 \pm 0.2$ & $1.7 \pm 0.1$ & $3.2 \pm 0.2$ & $6.6 \pm 0.1$ & $0.12 \pm 0.001$ \\
\hline \multirow{3}{*}{ T1 (background) } & \multirow{6}{*}{ T. laxmannii } & Stem & $93 \pm 7$ & $23.8 \pm 1.5$ & $3.5 \pm 0.4$ & $1.9 \pm 0.2$ & $\mathbf{0 . 6} \pm 0.2$ & $1.2 \pm 0.1$ & $0.08 \pm 0.01$ \\
\hline & & Root & $89 \pm 6$ & $45.6 \pm 1.8$ & $6.8 \pm 0.5$ & $0.3 \pm 0.01$ & $2.2 \pm 0.3$ & $2.8 \pm 0.4$ & $0.04 \pm 0.004$ \\
\hline & & Inflorescence & $42 \pm 3$ & $43.2 \pm 2.5$ & $5.7 \pm 0.4$ & $2.8 \pm 0.1$ & $\mathbf{1 . 8} \pm 0.4$ & $0.6 \pm 0.1$ & $0.15 \pm 0.02$ \\
\hline \multirow{3}{*}{ T4 (polluted) } & & Stem & $428 \pm 31$ & $\mathbf{1 0 8 . 6} \pm 12.9$ & $26.1 \pm 0.3$ & $7.6 \pm 0.1$ & $4.2 \pm 1.0$ & $\mathbf{1 2 . 9} \pm 0.6$ & $\mathbf{0 . 5 1} \pm 0.02$ \\
\hline & & Root & $318 \pm 27$ & $\mathbf{1 9 5 . 1} \pm 13.5$ & $31.5 \pm 0.6$ & $10.9 \pm 0.1$ & $5.1 \pm 0.6$ & $\mathbf{1 2 . 4} \pm 0.5$ & $\mathbf{0 . 6 7} \pm 0.02$ \\
\hline & & Inflorescence & $142 \pm 21$ & $65.9 \pm 3.6$ & $21.0 \pm 0.6$ & $6.4 \pm 0.2$ & $3.8 \pm 1.0$ & $\mathbf{1 1 . 1} \pm 0.9$ & $0.28 \pm 0.005$ \\
\hline $\begin{array}{c}\text { Maximum permissible } \\
\text { level [50] }\end{array}$ & & & - & 50.0 & 30.0 & 5.0 & 0.5 & 3.0 & 0.3 \\
\hline
\end{tabular}

Exceedance of the maximum permissible level for grasses is typed in bold. 
Table 3. Effects of the plant species characteristics and pollution level expressed by the integral pollution index $(\mathrm{Zc})$ on morphobiometric parameters of cattails as indicated by factorial ANOVA.

\begin{tabular}{ccccccc}
\hline \multirow{2}{*}{ Parameter } & \multicolumn{2}{c}{ Plant Species } & \multicolumn{2}{c}{ Zc } & \multicolumn{2}{c}{ Plant Species * Zc } \\
\cline { 2 - 7 } & $\boldsymbol{F}$ & $\boldsymbol{p}$ & $\boldsymbol{F}$ & $\boldsymbol{p}$ & $\boldsymbol{F}$ & $\boldsymbol{p}$ \\
\hline Spike height & 484.7 & $<0.0001$ & 139.8 & $<0.0001$ & 60.0 & $<0.0001$ \\
Spike diameter & 32.0 & $<0.0001$ & 0.9 & 0.3410 & 52.7 & $<0.0001$ \\
Stem height & 198.6 & $<0.0001$ & 27.9 & $<0.0001$ & 14.0 & $<0.0001$ \\
\hline
\end{tabular}

Based on the results of the Tukey post hoc multiple comparisons tests, it can be noted that the stem height and spike height of T. laxmannii are significantly smaller than those of T. australis. Soil pollution leads to a decrease in the size of vegetative and generative organs of T. australis; however, it is less resistant to soil pollution since a statistically significant difference between the mean values was obtained when comparing the spikes of plants in the background and polluted plots (Table 3). Thus, a morphological comparison of the two species of cattails showed that T. laxmannii was more resistant to PTE pollution.

The T. australis plants were characterized by significant differences in spike height and diameter between plants from the background plot and the polluted plot. It was found that T. australis from the polluted plot had shorter and thinner spikes (on average by $60 \%$ and $72 \%$, respectively) than plants from background plots (Figure 3). Hazardous soil pollution caused anomalies in the structure of the plant, which manifested itself in the formation of a lower, on average, higher and wider spike. The average height of T. australis growing on the background plot was $166.7 \pm 12.1 \mathrm{~cm}$, while on the polluted plot, it slightly decreased, on average, to $162.7 \pm 10.1 \mathrm{~cm}$.

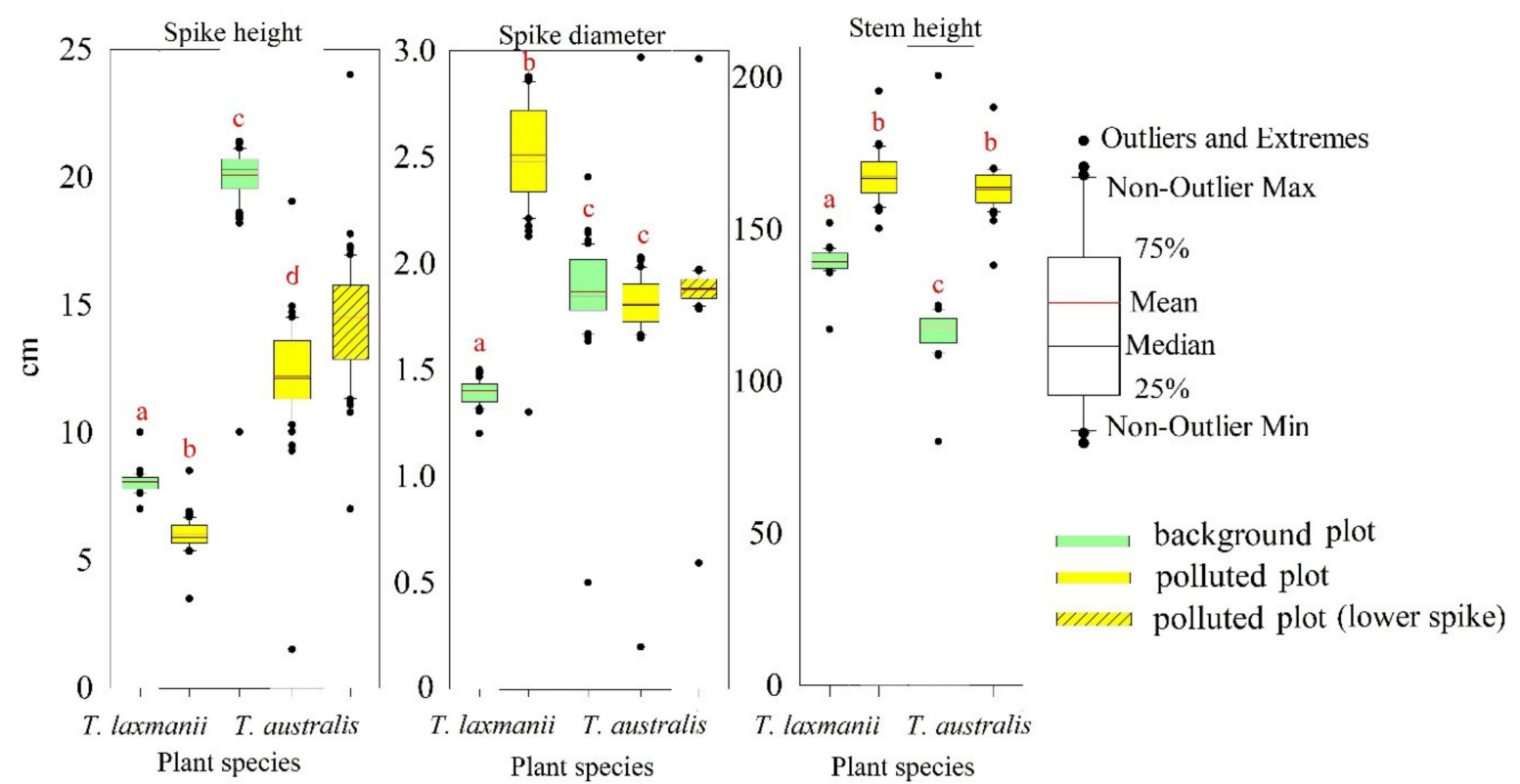

Figure 3. Morphobiometric parameters of T. australis and T. laxmannii growing in the background and polluted plots. Soil pollution resulted in the formation of the lower spike of T. australis (shown by hatching). Different letters indicate significant differences $(p<0.05)$ resulting from the post hoc Tukey's-honestly significant difference (HSD) test.

In T. laxmannii, no massive development of the second spike was noted. Plants on the polluted plot were visually in a depressed and deformed state with very narrow or short spikes, resembling a ball or completely underdeveloped (Figure $2 \mathrm{~g}-\mathrm{i}$. T. laxmannii from the polluted plot had shorter and thicker spike (on average by $77 \%$ and $138 \%$, respectively) than the plants from background plots (Figure 3): the spike height decreases by $1.81 \mathrm{~cm}$ and the spike diameter increases by $0.52 \mathrm{~cm}$. The height of T. laxmannii from the polluted plot 
was $82 \%$ compared to that of plants from the background plot: the stem height decreases on average by $23.2 \mathrm{~cm}$ (Figure 3 ).

Depending on the level of pollution, different variability of morphobiometric parameters of both T. australis and T. laxmannii was noted. Both cattail species were characterized by low variability of the height and diameter of the spike and the stem height: $\mathrm{CV}$ was $10.5 \%, 9.6 \%$ and $7.2 \%$ for T. australis, respectively, and $10.0 \%, 6.5 \%$ and $8.7 \%$ for T. laxmannii, respectively. At the same time, a more pronounced variation of morphobiometric characteristics was observed in the polluted areas: the $\mathrm{CV}$ of individual parameters of T. australis did not exceed $25 \%$, and the CV for T. laxmannii reached $21.3 \%$.

\subsection{Anatomical Microscopic Study of the Plants T. australis and T. laxmannii \\ 3.3.1. Root}

It is noted that thin branching water roots are located in the plagiotropic zone of the rhizome, and relatively thick, less branching soil roots are located in the orthotropic zone of the rhizome. On a cross-section of roots, thin-walled parenchymal cells were located in the primary cortex between epiderm (Ep) and endoderm (EN). In the mesoderm, air channels delimited from each other by several layers of parenchymal cells were found (Figure $4 \mathrm{a}, \mathrm{c})$. Deep behind the endoderm, an axial cylinder (AC) with conductive elements is located.
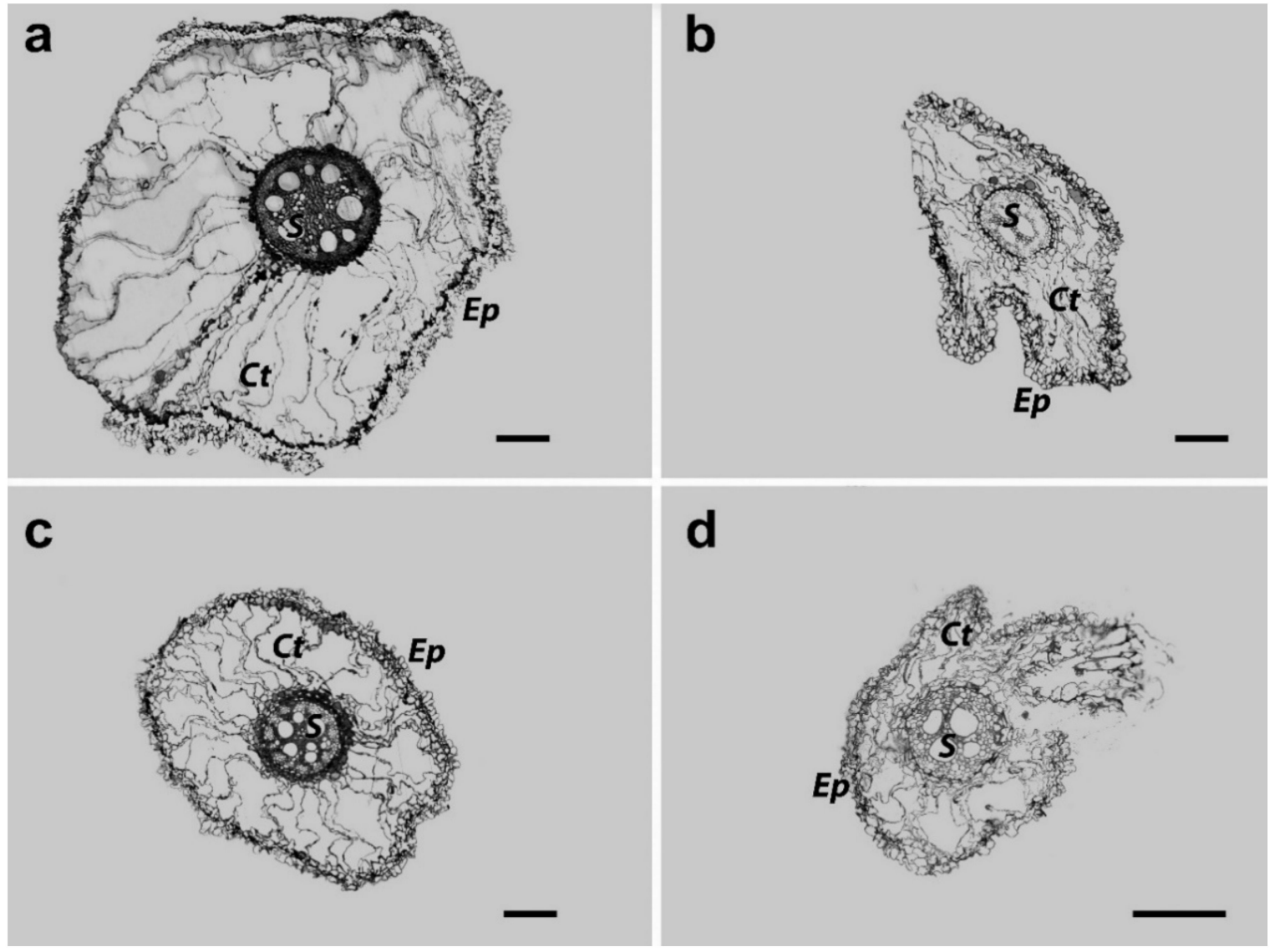

Figure 4. Cross-section of the roots; T. australis: (a) background plot (5K), (b) polluted plot (8K); T. laxmannii: (c) background plot (T1), (d) polluted plot (T4). Ep—epidermal cells; Ct—cortex; S—central cylinder (stele). The scale bar is $100 \mu \mathrm{m}$.

In plants grown on polluted soils, the root diameter was significantly smaller than in the samples from a background site. Disturbance of the ordered arrangement of exoderm cells was also noted (Figure $4 \mathrm{~b}, \mathrm{~d}$ ) along with a cylinder with a decrease in the optical density of the central cylinder structures. They found changes in the anatomical structure 
(the relative area of the air cavities on the cross-section) of the cattail roots in pollution conditions, as well as in the background samples, depended on the cattail species.

The proportion of air cavities in the total cross-sectional area of soil roots varied significantly both under different pollution conditions and depended on the type of cattail, which is shown by the results of ANOVA (Table 4). Soil pollution leads to a decrease in the proportion of air cavities in the roots of both cattail species (Figure 5). A pairwise comparison by Tukey's test showed that differences in the relative area of air cavities between T. laxmannii and T. australis are manifested only under hazardous pollution.

Table 4. Effects of the plant species characteristics and pollution level according to the integral pollution index (Zc) on microstructural characteristics of cattails as indicated by factorial ANOVA.

\begin{tabular}{ccccccc}
\hline \multirow{2}{*}{ Parameter } & \multicolumn{2}{c}{ Plant Species } & \multicolumn{2}{c}{ Zc } & \multicolumn{3}{c}{ Plant Species *Zc } \\
\cline { 2 - 7 } & $\boldsymbol{F}$ & $\boldsymbol{p}$ & $\boldsymbol{F}$ & $\boldsymbol{p}$ & $\boldsymbol{F}$ & $\boldsymbol{p}$ \\
\hline Percentage of air cavities on the cross-section of the roots & 185.8 & $<0.0001$ & 536.0 & $<0.0001$ & 48.0 & $<0.0001$ \\
Percentage of parenchyma on the cross-section of the leaf & 29.2 & $<0.0001$ & 14.8 & $<0.0001$ & 109.1 & $<0.0001$ \\
\hline
\end{tabular}

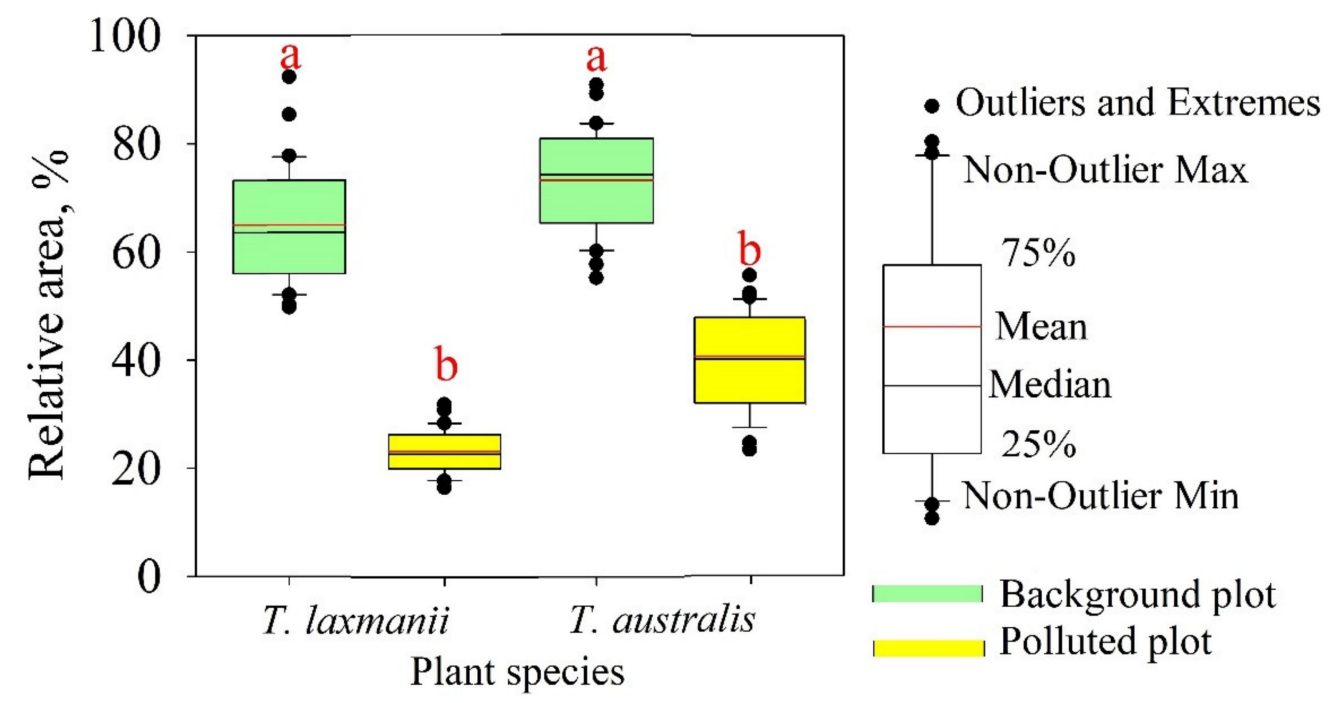

Figure 5. Relative area of air cavities on the cross-section of soil roots of T. australis and T. laxmannii growing in the background and polluted plots. Different letters indicate significant differences $(p<0.05)$ resulting from the post hoc Tukey's HSD test.

Analysis of electronic images showed that, in the background, root cells of T. australis and T. laxmannii characterized with normal ultrastructural characteristics including whole cell walls, cytoplasmic membranes, and a large central vacuole (Figure 6a,c). 

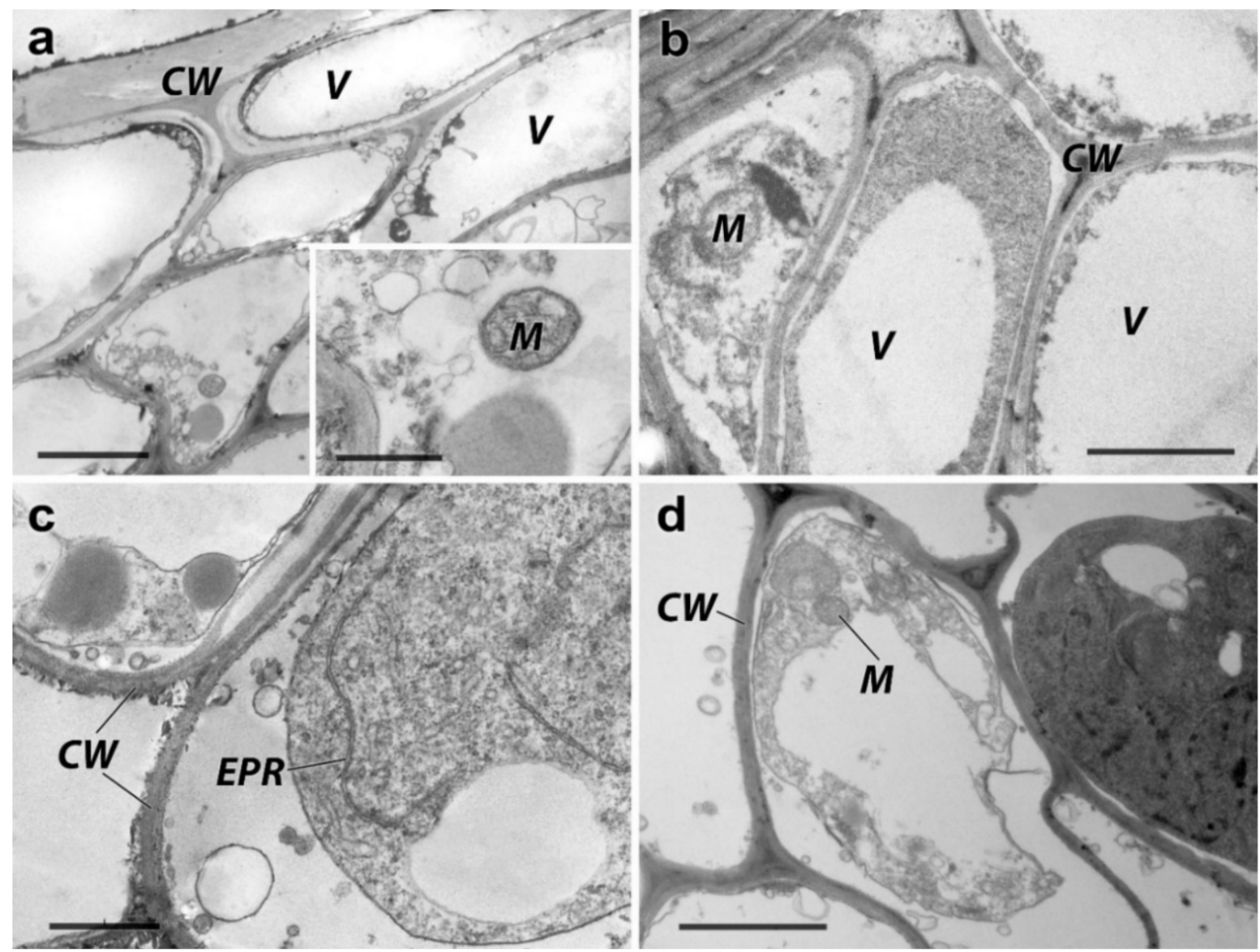

Figure 6. TEM micrographs of ultrathin cross-sections of the roots; T. australis: (a) background plot (5K), (b) polluted plot (8K); T. laxmannii: (c) background plot (T1), (d) polluted plot (T4). M-mitochondria; CW-cell wall; V—vacuole; EPR—endoplasmic reticulum. The scale bar is $(\mu \mathrm{m})$ : (a) -0.7 , inset-1, (b) $-2,(\mathbf{c})-1,(\mathbf{d})-2$.

Comparative analysis showed some ultrastructural changes in the roots of T. australis from polluted soil. The mitochondrial matrix was lighter, and the cristae in most of the organelles were destroyed (Figure 6b). In individual cells, the integrity of cell membranes was broken, and the cytoplasm got into the central vacuole. In the roots of T. laxmannii plants grown on polluted soil, the ultrastructure of organelles in most of the cells was not disturbed (Figure 6d). The ultrastructure of organelles in most of the cells was integrated into the roots of T. laxmannii grown on polluted soil.

\subsubsection{Leaves}

Hydrophytes T. australis and T. laxmannii were characterized by a thick leaf lamina and a lateral-palisade type of mesophyll. Assimilation tissue was divided into palisade and spongy (Figure 7a,b); air cavities (sac), which forms a complex tracheal system, were well expressed (Bk). The surface of the leaf was covered with an epidermis composed of tight-fitting epidermal cells (Ep). The space between the adaxial and abaxial epidermis is occupied by mesophyll cells (Me). Exposure to PTE toxicity on plants grown on polluted soil disrupted the arrangement of epidermal cells and decreased the number of mesophyll cells (Figure 7c,d). 


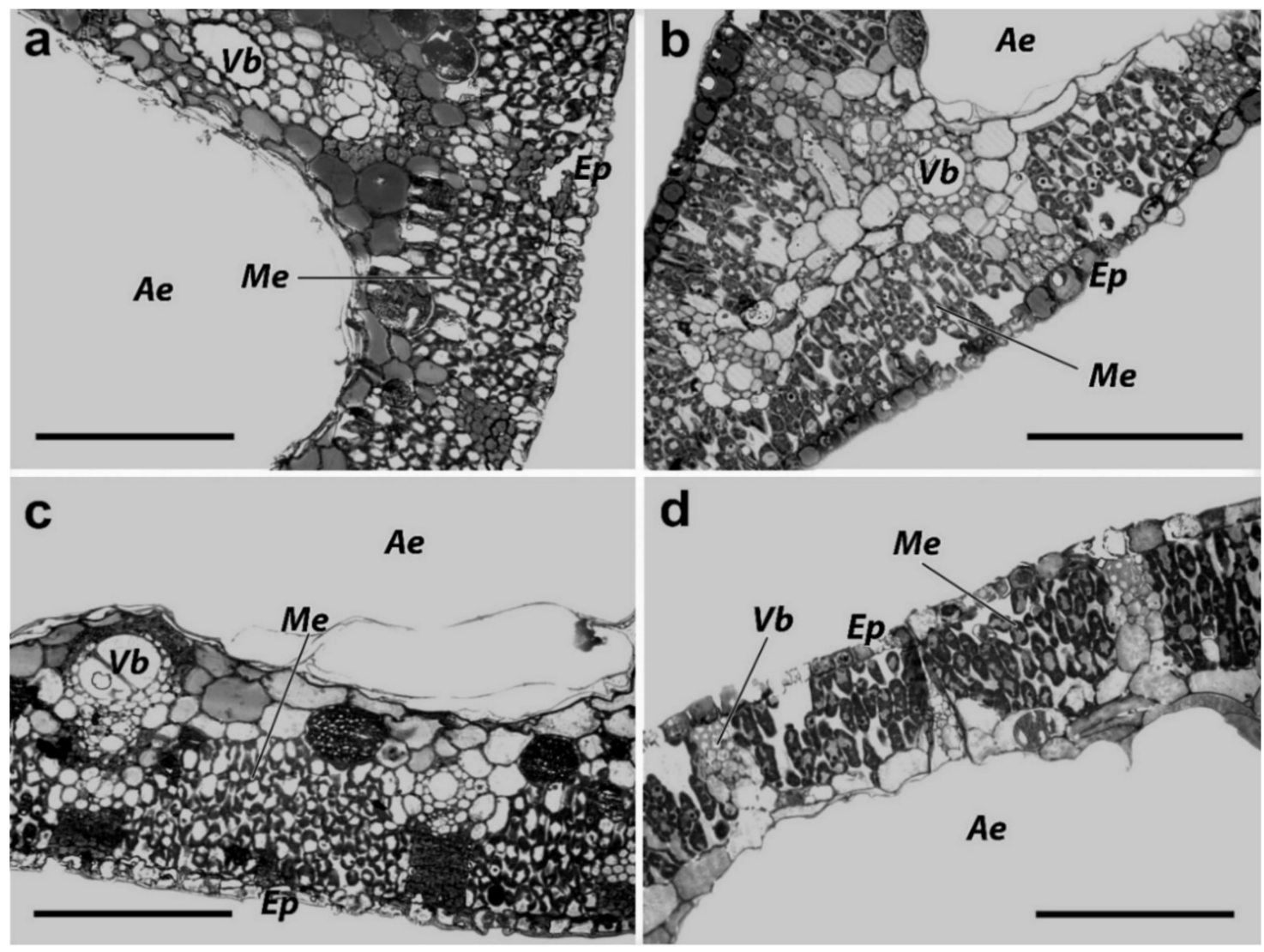

Figure 7. Cross-section of the leaves; T. australis: (a) background plot (5K), (b) polluted plot (8K); T. laxmannii: (c) background plot (T1), (d) polluted plot (T4). Me;-mesophyll; Ae-aerenchyma; Vb-vascular bundle. The scale bar is $100 \mu \mathrm{m}$.

There were no statistically significant differences between the two species of cattail in the relative proportion of parenchyma in the cross-section of the leaf when the plants grew on background soil. The results of Tukey's multiple comparisons showed that under hazardous conditions, there was a statistically significant $(p<0.05)$ decrease in the proportion of parenchyma area for T. australis, while for T. laxmannii, the opposite trend was observed (Figure 8).
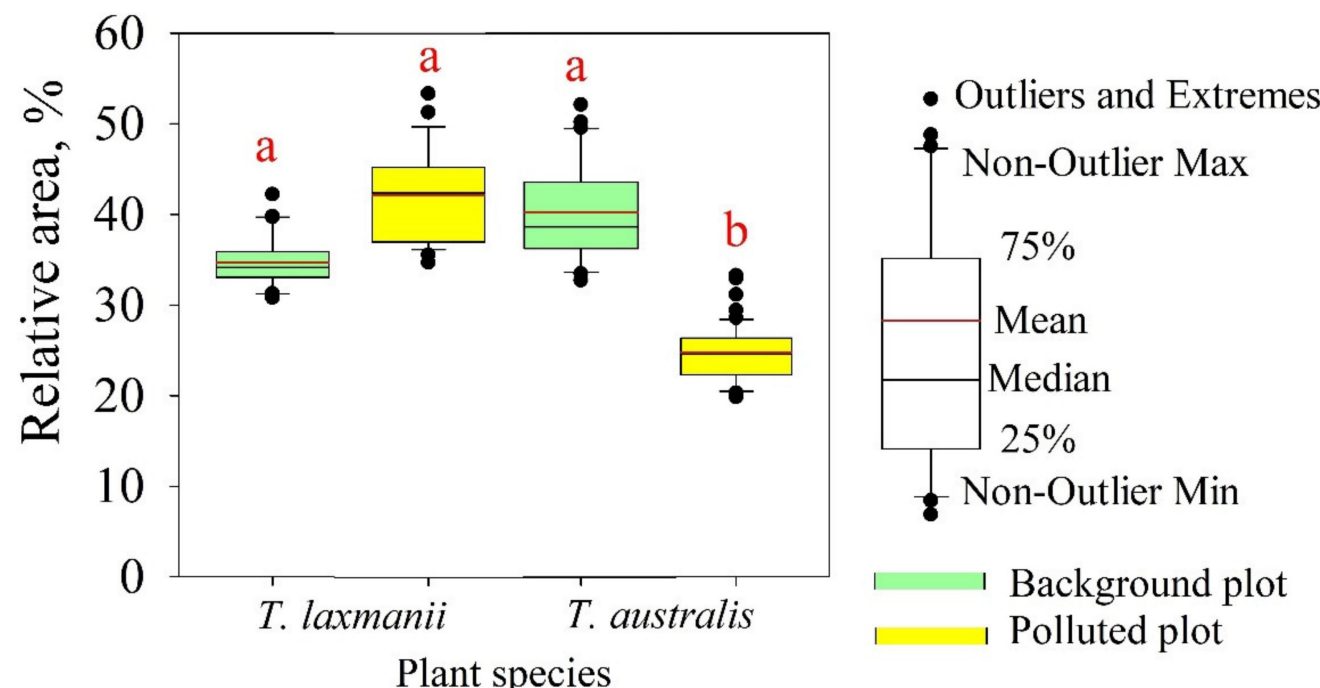

Figure 8. Relative area of parenchyma on the cross-section of the leaf of T. australis and T. laxmannii growing in the background and polluted plots. Different letters indicate significant differences $(p<0.05)$ resulting from the post hoc Tukey's HSD test. 
Visual analysis of the electron images of the background samples showed that the ultrastructure of the mesophilic cells of T. australis and T. laxmannii are similar to each other (Figure 9). Nearly elliptical chloroplasts contained a matrix of higher electron density and grana with a number of thylakoids 20-30 units (Figure 9a,c, inset). Single stromal thylakoids were slightly swollen. The number of plastoglobules in the organelle reached four units or more, and the diameter varied from $0.4 \mu \mathrm{m}$. The content of plastoglobules had heterogenic density: along the perimeter (narrow strip), and the degree of density was significantly higher. Oval mitochondria contained a moderately dense matrix with numerous and slightly swollen cristae. Ribosomes were located between cell organelles, which concentration in the cytoplasm was significantly high. Peroxisomes had a fine-grained matrix with a diameter of about $0.5-0.8 \mu \mathrm{m}$. The elongated nucleus was separated from the cytoplasm by a double-circuit membrane. Chromatin generally distributed within the entire nucleus, and single condensed globules were localized along the karyolemma (Figure 9a,c).

Plastids of T. australis plants grown on polluted soil characterized by higher electron density (Figure 9b). Large plastoglobules (more than $0.5 \mu \mathrm{m}$ in diameter), which had higher electron density, were located throughout the entire area of the organelle, and their number in the organelle can reach seven units or more. The granulation process in plastids is disturbed; their stroma was almost completely filled with expanded thylakoids (Figure 9b, inset). The shape of most mitochondria was round, the matrix is clear, and the organelles looked swollen. The degree of swelling of mitochondria was different, the cristae in the swollen organelles were destroyed, and the matrix was fragmented. A few peroxisomes contained a low-density fine-grained matrix in the peripheral zone.
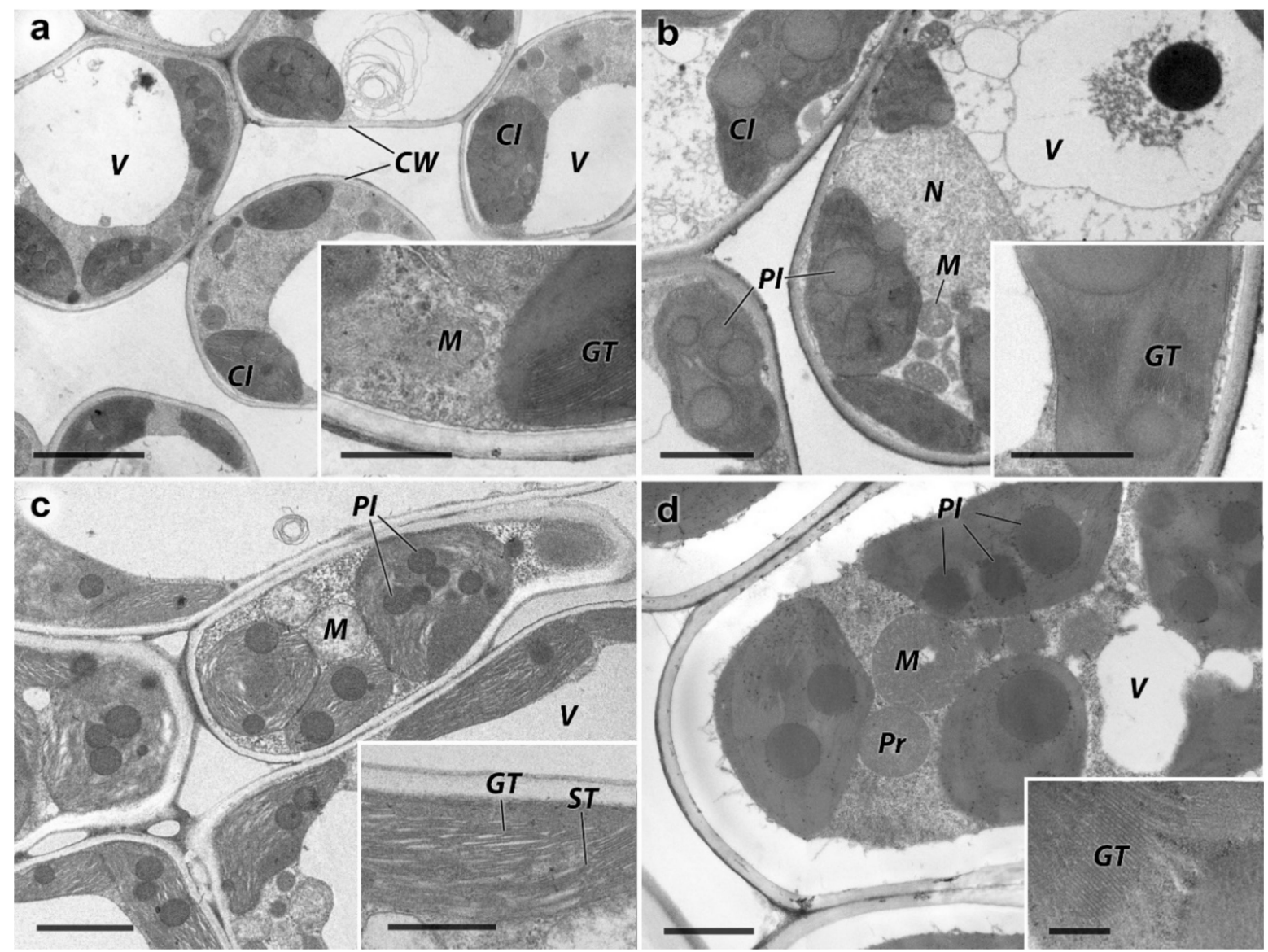

Figure 9. TEM micrographs of ultrathin cross-sections of the leaves; T. australis: (a) background plot (5K), (b) polluted plot (8K); T. laxmannii: (c) background plot (T1), (d) polluted plot (T4); CW-cell wall. Cl—chloroplast; P—plastoglobule; GT—thylakoids gran; ST—-thylakoids strom; N-nucleus; M-mitochondria; Pr-peroxisome, V—vacuole. The scale bar is $(\mu \mathrm{m})$ : (a) -3 , inset -0.4 , (b) -2 , inset -1 , (c) -2 , inset-1, (d) -4 , inset -0.25 . 
The significant detachment of the cytoplasm containing organelles from the cell wall (Figure 9d) was observed in the chlorenchymal cells of the leaves of T. laxmannii growing on the polluted site. The cytoplasm was significantly vacuolated, and the central vacuole was weakly expressed. Thylakoids were weakly signified in the dark matrix fond of the organelle and were localized mainly in granas with the number of lamellae up to 30 units (Figure 9d, inset). Electron-dense plastoglobules (about $0.5 \mu \mathrm{m}$ in diameter) were located throughout the entire plastid area compared to the plants from the background plots. The concentration of ribosomes in the cytoplasm was relatively low. Most mitochondria $(0.8 \mu \mathrm{m}$ in diameter) were round-shaped with a light central area of the matrix. A few peroxisomes contained a low-density fine-grained matrix with a diameter of $0.4 \mu \mathrm{m}$.

\section{Discussion}

The total content of PTE in background soils is characterized by an uneven distribution: $\mathrm{Mn}>\mathrm{Cr}>\mathrm{Zn}>\mathrm{Cu}>\mathrm{Ni}>\mathrm{Pb}>\mathrm{Cd}$ (Table 1). The total content of PTEs in polluted soils increased and its distribution changed to $\mathrm{Mn}>\mathrm{Zn}>\mathrm{Cr}>\mathrm{Cu}>\mathrm{Ni}>\mathrm{Pb}>\mathrm{Cd}$. The total $\mathrm{Zn}$ content in the polluted soils was seven times higher than in the background soils due to the influence of local sources of pollution such as settlements, high-traffic roads, the close location of the terminals of the Taganrog seaport, industrial enterprises, etc. It was found that the contamination category of the monitoring plots $8 \mathrm{~K}$ and T4 was hazardous according to $\mathrm{Zc}$ values due to its location in the hot spots of high anthropogenic activity. The study area covers one of the most densely populated regions in Southern Russia with high economic activity and environmental impact on the watershed areas and in the water basin [15,56-59]. Moreover, the river-sea transition zone is considered as part of a marginal filter or a cascade of barrier zones with avalanche sedimentation, mixing and transformation of the river and sea waters with a large number of biogenic elements, organic and inorganic pollutants [60-65].

The assignment of the soils of the monitoring plots to the hazardous category of pollution correlated with the pollution of plants growing on these plots. According to these pollution categories, the use of these soils for crop cultivation should be limited, and the cultivation of accumulating plants should be excluded.

The resistance mechanisms of cattails, reflecting the interaction of organs in the system of a whole plant, were manifested under conditions of anthropogenic impact at the organismic level. The delay in the consumption of PTE by roots and the ability of a plant to regulate their transport from roots to vegetative organs can be attributed to the mechanisms, which determine the resistance of the studied plants to PTE. This occurs due to the activity of several barriers to the transport of metals into the organs most important for the life of plants $[66,67]$. In both species of cattail, regardless of the pollution conditions, the highest concentrations of $\mathrm{Zn}, \mathrm{Cu}, \mathrm{Cr}$ and $\mathrm{Ni}$ were observed in the underground parts of plants (Table 2), which is due to the barrier function of the root system [15]. Under pollution conditions, the maximum Mn content was noted in the inflorescence of T. australis and in the stem of T. laxmannii. The background plots are characterized by a high $\mathrm{Pb}$ content in the inflorescence of both cattail species, while under pollution, the maximum $\mathrm{Pb}$ content is observed in the roots of both T. australis and T. laxmannii.

The plasticity of plant morphology allows them to successfully adapt to environmental conditions. The manifestation of an ecological stress factor in specific bioaccumulation and distribution of PTE in plant tissues, as well as at the morphological and anatomical level by the type of proliferation, was found in T. australis [35].

Mass appearance of the second spike (proliferation) was not observed in T. laxmannii. However, the plants on polluted soils were visually in a depressed and deformed state with massive manifestations of hypogenesis (Figure 2). The deformations of the spikes, possibly, could be considered on one hand, as an adaptive mechanism, on the other hand, as pathological changes in the structure of cattails. A morphological comparison of two species of cattails showed that T. laxmannii is more resistant to PTE pollution. Light-optical microscopy of samples revealed a significant reduction of the root and trachea's size under 
the toxic effects of PTE. Simultaneously, the most drastic decrease in the area of the trachea (more than 24\%) was found in T. australis (and only 7\% for T. laxmannii). A decrease of the aeration degree was also noted in the aquatic roots of another hydrophyte, T. angustifolia, under pollution with lead acetate-2.5.10-1 mg/L [68]. Obviously, these structural changes in the root, indirectly contacting dissolved compounds, allowed the plants to adapt to unfavorable environmental conditions.

Structural and functional features revealed by transmission electron microscopy in the roots of T. australis on polluted soil showed changes in the fine structure of some organelles, in particular, mitochondria. This observation is consistent with other reports [16,35]. Similar ultrastructural changes were noted in T. angustifolia under the toxic effect of $\mathrm{Pb}\left(\mathrm{NO}_{3}\right)_{2}(20,000 \mathrm{mg} / \mathrm{L})$ and included partial degradation of the cell wall of the root parenchyma [35]. Destructive changes in cytoplasmic membranes, mitochondria, and cell vacuoles were revealed after the treatment of the roots of $T$. angustifolia seedlings with $\mathrm{Cr}, \mathrm{Cd}$, and $\mathrm{Pb}$ [56]. In addition, the leaves of these plants were characterized by disorganization of the thylakoid system and vacuolization of chloroplasts that, according to the authors, are adaptive features and lie in the basis of the homeostatic mechanisms providing the resistance (tolerance) of plants to environmental pollution. Structural and functional changes in the compensatory character of the photosynthetic apparatus of $T$. latifolia are described under toxic impact with nine metals $(\mathrm{Cd}, \mathrm{Pb}, \mathrm{Ni}, \mathrm{Cu}, \mathrm{Fe}, \mathrm{Hg}, \mathrm{Co}, \mathrm{Zn}$, Mn) [69].

It is known that the energy required for development and response to stress is provided by photosynthesis, and the photosynthetic activity of the leaf is closely related to its structure. The chlorophyll parenchyma is the main place of photosynthesis in plants. The relative area of the chlorophyll parenchyma on the cross-section of the leaves of T. australis and T. laxmannii was approximately the same in background plots. As a result of the toxic PTE effect, the relative area of the parenchyma decreased (up to $25 \%$ ) in T. australis and increased (up to $43 \%$ ) in T. laxmannii compared to the plants from the background plots.

We found that the ultrastructure of the mesophilic cells of T. australis and T. laxmannii is similar to other hydrophytes described in early studies $[14,31,56]$. Chloroplasts, peroxisomes and mitochondria are the main organelles of photosynthesis and serve as a source of intermediates for various metabolic syntheses. The destructive changes in cell organelles found in this study, and earlier [31] are obviously associated with a decrease in the level of metabolic processes supporting plant growth. Ultrastructural changes, most expressed in T. australis, conform to their morphometric parameters. Structural changes in T. laxmannii are compensatory because its growth parameters such as spike diameter indicated a significantly high resistance of this species of cattail to prolonged technogenic impact.

\section{Conclusions}

The impact of the environmental stress factor was found to be manifested not only in the features of PTE contain and distribution in plant tissues but also at the morphological and anatomical level according to the type of proliferation. A decrease in the content of elements in two species of cattails on the polluted plots occurred in the following order: roots/rhizomes $>$ stems $\geq$ inflorescences.

Soil pollution leads to the accumulation and distribution of PTE in plant tissues, as well as to the changes in the morphological-anatomical level. Mass appearance of the second spike (proliferation) was not observed in T. laxmannii. However, the plants on polluted soils were visually in a depressed and deformed state with the massive manifestation of hypogenesis. Microscopic analysis of structural changes of the plants showed that the degree and nature of ultrastructural change in cattails were significantly different and most pronounced in the assimilation tissue of leaves at the same level of soil pollution. Thus, all changes in the ultrastructure of organelles were probably one of the mechanisms for the optimization of energy metabolism in conditions of environmental pollution. 
Author Contributions: Conceptualization, supervision, project administration and funding acquisition, T.M.; microscopic analysis, G.F. and A.F.; geochemical analysis, D.N.; morphometric analysis, T.P.; statistical analysis, T.P. and T.D.; investigation, D.N., V.C. and T.H.; writing-original draft preparation, G.F., D.N., T.P., V.C., S.M. and T.H.; writing-review and editing, T.M., D.N., T.D., E.K. and S.M.; visualization, D.N., A.F. and T.D. All authors have read and agreed to the published version of the manuscript.

Funding: This research was funded by the Russian Science Foundation, project no. 20-14-00317.

Institutional Review Board Statement: Not applicable.

Informed Consent Statement: Not applicable.

Data Availability Statement: The data presented in this study are available on request from the corresponding author. The data are not publicly available due to the raw / processed data required to reproduce these findings cannot be shared at this time as the data also forms part of an ongoing study.

Conflicts of Interest: The authors declare no conflict of interest. The funders had no role in the design of the study; in the collection, analyses, or interpretation of data; in the writing of the manuscript; or in the decision to publish the results.

\section{Appendix A}

Table A1. Physical and chemical properties of fluvisols at the monitoring plots on the sea edge of the Don River delta, 0-20 cm layer.

\begin{tabular}{|c|c|c|c|c|c|c|c|c|c|}
\hline \multirow{2}{*}{$\begin{array}{l}\text { Monitoring } \\
\text { Plot }\end{array}$} & \multirow{2}{*}{$\begin{array}{c}\text { Corg, } \\
\%\end{array}$} & \multirow{2}{*}{$\mathrm{pH}$} & \multirow{2}{*}{$\begin{array}{c}\mathrm{CaCO}_{3} \\
\%\end{array}$} & \multirow{2}{*}{$\begin{array}{c}\text { Dense } \\
\text { Residue, \% }\end{array}$} & \multicolumn{2}{|c|}{$\begin{array}{l}\text { Exchangeable Cations, } \\
\mathrm{cmol} / \mathrm{kg}\end{array}$} & \multicolumn{3}{|c|}{ Particle Size Fractions (mm), \% } \\
\hline & & & & & $\mathrm{Ca}^{2+}$ & $\mathrm{Mg}^{2+}$ & $\begin{array}{c}\text { Sand } \\
(1.0-0.05 \\
\mathrm{mm}), \%\end{array}$ & $\begin{array}{l}\text { Silt (0.01- } \\
0.001 \\
\mathrm{~mm}), \%\end{array}$ & $\begin{array}{c}\text { Clay }(<0.001 \\
\text { mm), \% }\end{array}$ \\
\hline $\begin{array}{c}5 \mathrm{~K} \\
\text { (background) }\end{array}$ & $\begin{array}{c}1.7 \pm \\
0.1\end{array}$ & $\begin{array}{c}7.6 \pm \\
0.3\end{array}$ & $\begin{array}{c}3.4 \pm \\
0.1\end{array}$ & $\begin{array}{c}0.102 \pm \\
0.004\end{array}$ & $31.3 \pm 2.0$ & $4.2 \pm 0.1$ & $86.0 \pm 5.5$ & $7.3 \pm 0.5$ & $6.7 \pm 0.8$ \\
\hline 8K (polluted) & $\begin{array}{c}1.9 \pm \\
0.1\end{array}$ & $\begin{array}{c}8.1 \pm \\
0.3\end{array}$ & $\begin{array}{c}1.8 \pm \\
0.1\end{array}$ & $\begin{array}{c}0.143 \pm \\
0.007\end{array}$ & $29.9 \pm 1.5$ & $6.4 \pm 0.2$ & $81.0 \pm 4.7$ & $10.9 \pm 0.7$ & $8.1 \pm 0.9$ \\
\hline $\begin{array}{c}\mathrm{T} 1 \\
\text { (background) }\end{array}$ & $\begin{array}{c}1.6 \pm \\
0.1\end{array}$ & $\begin{array}{c}7.5 \pm \\
0.2\end{array}$ & $\begin{array}{c}2.1 \pm \\
0.1\end{array}$ & $\begin{array}{c}0.095 \pm \\
0.004\end{array}$ & $28.0 \pm 1.5$ & $3.9 \pm 0.1$ & $83.1 \pm 5.0$ & $9.3 \pm 0.6$ & $7.6 \pm 0.6$ \\
\hline T4 (polluted) & $\begin{array}{c}1.7 \pm \\
0.1\end{array}$ & $\begin{array}{c}8.1 \pm \\
0.2\end{array}$ & $\begin{array}{c}2.5 \pm \\
0.1\end{array}$ & $\begin{array}{c}0.128 \pm \\
0.007\end{array}$ & $26.5 \pm 1.3$ & $7.0 \pm 0.3$ & $81.6 \pm 4.5$ & $11.5 \pm 0.9$ & $6.9 \pm 0.4$ \\
\hline
\end{tabular}

\section{References}

1. Dolgov, S.V. Hydroecological consequences of changes of anthropogenic impact on the watersheds of the southern part of Russia in 1990s. In Anthropogenic Impact on the Water Resources of Russia and Neighboring States by the End of the 20th Century; Koronkevich, N.I., Zaitseva, I.S., Eds.; Nauka: Moscow, Russia, 2003; pp. 241-266. (In Russian)

2. Matishov, G.G.; Il'in, G.V.; Savinova, T.N.; Chernyak, S.M. Pollutant levels in the Azov Sea sediments. In The Pattern of Oceanographic and Biological Processes in the Sea of Azov; Kola Scientific Center Publishing, Russian Academy of Sciences: Apatity, Russia, 2000; pp. 82-88. (In Russian)

3. Korotova, L.G.; Smirnov, M.P.; Klimenko, O.A.; Zhemchugova, N.V.; Dubovikova, G.F. Brinning out of mineral, biogenic and pollutants by rivers into the Sea of Azov basin. In Ecosystem Studies of the Sea of Azov and Its Coast; Kola Scientific Center Publishing, Russian Academy of Sciences: Apatity, Russia, 2002; pp. 29-39. (In Russian)

4. Nikanorov, A.M.; Khoruzhaya, T.A.; Mironova, T.V. The dynamics of toxical pollution of the Don River delta. In Ecosystem Studies of the Sea of Azov and Its Coast; Kola Scientific Center Publishing, Russian Academy of Sciences: Apatity, Russia, 2002; pp. 79-90. (In Russian)

5. Klenkin, A.A.; Korpakova, I.G.; Pavlenko, L.F.; Temerdashev, Z.A. Ecosystem of the Sea of Azov: Anthropogenic Pollution; Prosveshchenie-Yug: Kransodar, Russia, 2007. (In Russian)

6. Qyli, M.; Aliko, V.; Faggio, C. Physiological and biochemical responses of Mediterranean green crab, Carcinus aestuarii, to different environmental stressors: Evaluation of hemocyte toxicity and its possible effects on immune response. Compar. Biochem. Physiol. Part C Toxicol. Pharmacol. 2020, 231, 108739. [CrossRef] [PubMed] 
7. Cuong, T.D.; Obbard, J.P. Metal speciation in coastal marine sediments from Singapore from Singapore using a modified BCRsequential extraction procedure. Appl. Geochem. 2006, 21, 1335-1346. [CrossRef]

8. Ernst, W.H.O. Evolution of metal tolerance in higher plants. For. Sn. Landsc. Res. 2006, 80, 251-274.

9. Chaney, R.L.; Angle, J.S.; Broadhurst, C.L.; Peters, C.A.; Tappero, R.V.; Sparks, D.L. Improved phytoextraction and phytomining technologies. J. Environ. Qual. 2007, 36, 1429-1443. [CrossRef] [PubMed]

10. Bansal, S.; Lishawa, S.C.; Newman, S.; Tangen, B.A.; Wilcox, D.; Albert, D.; Windham-Myers, L. Typha (Cattail) Invasion in North American Wetlands: Biology, Regional Problems, Impacts, Ecosystem Services, and Management. Wetlands 2019, 39, 645-684. [CrossRef]

11. Rai, P.K. Heavy Metal Phytoremediation from Aquatic Ecosystems with Special Reference to Macrophytes. Crit. Rev. Environ. Sci. Technol. 2009, 39, 697-753. [CrossRef]

12. Klink, A. A comparison of trace metal bioaccumulation and distribution in Typha latifolia and Phragmites australis: Implication for phytoremediation. Environ. Sci. Pollut. Res. 2016, 24, 3843-3852. [CrossRef]

13. Klink, A.; Polechońska, L.; Cegłowska, A.; Stankiewicz, A. Typha latifolia (broadleaf cattail) as bioindicator of different types of pollution in aquatic ecosystems-application of self-organizing feature map (neural network). Environ. Sci. Pollut. Res. 2016, 23, 14078-14086. [CrossRef]

14. Kumari, M.; Tripathi, B.D. Efficiency of Phragmites australis and Typha latifolia for heavy metal removal from wastewater. Ecotoxicol. Environ. Saf. 2015, 112, 80-86. [CrossRef]

15. Minkina, T.M.; Nevidomskaya, D.G.; Pol'shina, T.N.; Fedorov, Y.A.; Mandzhieva, S.S.; Chaplygin, V.A.; Bauer, T.V.; Burachevskaya, M.V. Heavy metals in the soil-plant system of the Don River estuarine region and the Taganrog Bay coast. J. Soils Sediments 2017, 17, 1474-1491. [CrossRef]

16. Minkina, T.; Fedorenko, G.; Nevidomskaya, D.; Fedorenko, A.; Chaplygin, V.; Mandzhieva, S. Morphological and anatomical changes of Phragmites australis Cav. due to the uptake and accumulation of heavy metals from polluted soils. Sci. Total Environ. 2018, 636, 392-401. [CrossRef] [PubMed]

17. Bonanno, G.; Borg, J.A.; Di Martino, V. Levels of heavy metals in wetland and marine vascular plants and their biomonitoring potential: A comparative assessment. Sci. Total Environ. 2017, 576, 796-806. [CrossRef] [PubMed]

18. Parzych, A.; Cymer, M.; Macheta, K. Leaves and roots of Typha latifolia L. and Iris pseudacorus L. as bioindicators of contamination of bottom sediments by heavy metals. Limnolog. Rev. 2016, 16, 77-83. [CrossRef]

19. Klink, A.; Wisłocka, M.; Musiał, M.; Krawczyk, J. Macro- and trace-elements accumulation in Typha angustifolia L. and Typha latifolia L. organs and their use in bioindication. Pol. J. Environ. Stud. 2013, 22, 183-190.

20. Tangahu, B.V.; Sheikh Abdullah, S.R.; Basri, H.; Idris, M.; Anuar, N.; Mukhlisin, M. A review on heavy metals (As, Pb, and Hg) uptake by plants through phytoremediation. Int. J. Chem. Eng. 2011, 1-31. [CrossRef]

21. Hadad, H.R.; Mufarrege, M.M.; Pinciroli, M.; Di Luca, G.A.; Maine, M.A. Morphological response of Typha domingensis to an industrial effluent containing heavy metals in a constructed wetland. Arch. Environ. Contam. Toxicol. 2010, 58, 666-675. [CrossRef]

22. Chandra, R.; Yadav, S. Phytoremediation of $\mathrm{Cd}, \mathrm{Cr}, \mathrm{Cu}, \mathrm{Mn}, \mathrm{Fe}, \mathrm{Ni}, \mathrm{Pb}$ and $\mathrm{Zn}$ from aqueous solution using Phragmites $\mathrm{Cummunis,}$ Typha Angustifolia and Cyperus Esculentus. Int. J. Phytoremed. 2011, 13, 580-591. [CrossRef]

23. Mufarrege, M.M.; Di Luca, G.A.; Hadad, H.R.; Maine, M.A. Adaptability of Typha domingensis to high pH and salinity. Ecotoxicology 2011, 20, 457-465. [CrossRef]

24. Kapitonova, O.A. Specific anatomical features of vegetative organs in some macrophyte species under conditions of industrial pollution. Russ. J. Ecol. 2002, 33, 59-61. [CrossRef]

25. Hadad, H.R.; Maine, M.; Bonetto, C.A. Macrophyte growth in a pilot-scale constructed wetland for industrial wastewater treatment. Chemosphere 2006, 63, 1744-1753. [CrossRef]

26. Kamal, M.; Ghaly, A.E.; Mohmud, N.; Cote, R. Phytoaccumulation of heavy metals by aquatic plants. Environ. Int. 2004, 29, 1029-1039. [CrossRef]

27. Fritioff, A.; Greger, M. Uptake and distribution of $\mathrm{Zn}, \mathrm{Cu}, \mathrm{Cd}$, and $\mathrm{Pb}$ in an aquatic plant Potamogeton natans. Chemosphere 2006, 63, 220-227. [CrossRef] [PubMed]

28. Manios, T.; Stentiford, E.I.; Millner, P.A. The effect of heavy metals accumulation on the chlorophyll concentration of Typha latifolia plants, growing in a substrate containing sewage sludge compost and watered with metalliferous water. Ecol. Eng. 2003, 20, 65-74. [CrossRef]

29. Maleva, M.G.; Chukina, N.V.; Borisova, G.G.; Sinenko, O.S.; Shiryaev, G.I. Structural and functional changes in the photosynthetic apparatus of Typha latifolia L. under technogenic pollution. Probl. Reg. Ekol. 2019, 6, 24-26.

30. Verbruggen, N.; Hermans, C.; Schat, H. Molecular mechanisms of metal hyperaccumulation in plants. New Phytolog. 2009, 181, 759-776. [CrossRef] [PubMed]

31. Minkina, T.; Fedorenko, G.; Nevidomskaya, D.; Pol'shina, T.; Fedorenko, A.; Chaplygin, V.; Mandzhieva, S.; Sushkova, S.; Hassan, T. Bioindication of soil pollution in the delta of the Don River and the coast of the Taganrog Bay with heavy metals based on anatomical, morphological and biogeochemical studies of macrophyte (Typha australis Schum. \& Thonn). Environ. Geochem. Health 2019. [CrossRef]

32. Lang, I.; Wernitznig, S. Sequestration at the cell wall and plasma membrane facilitates zinc tolerance in the moss Pohlia drummondii. Environ. Exp. Bot. 2011, 74, 186-193. [CrossRef]

33. Colzi, I.; Doumett, S.; Del Bubba, M.; Fornaini, J.; Arnetoli, M.; Gabbrielli, R.; Gonnelli, C. On the role of the cell wall in the phenomenon of copper tolerance in Silene paradoxa L. Environ. Exp. Bot. 2011, 72, 77-83. [CrossRef] 
34. Fryzova, R.; Pohanka, M.; Martinkova, P.; Cihlarova, H.; Brtnicky, M.; Hladky, J.; Kynicky, J. Oxidative Stress and Heavy Metals in Plants. Rev. Environ. Contam. Toxicol. 2017, 245, 129-156. [CrossRef]

35. Panich-pat, T.; Srinives, P.; Kruatrachue, M.; Pokethitiyook, P.; Upatham, S.; Lanza, G.R. Electron Microscopic studies on localization of lead in organs of Typha angustifolia grown on contaminated soil. Sci. Asia 2005, 31, 49-53. [CrossRef]

36. Zhukova, S.V.; Syrovotka, N.I.; Belyaev, A.G.; Shishkin, V.M.; Kuropatkin, A.P.; Lutynskaya, L.A.; Fomenko, I.F. The Don River Delta: Evolution under Anthropogenic Run-off Transformation; Agapov, S.A., Ed.; FGUP “AzNIIRKH” Publishing: Rostov-on-Don, Russia, 2009; p. 184.

37. IUSS Working Group WRB. World Reference Base for Soil Resources 2014, Update 2015. International Soil Classification System for Naming Soils and Creating Legends for Soil Maps; World soil resources reports; Issue 106; FAO: Rome, Italy, 2015.

38. ISO 18400-104. Soil Quality_Sampling_Part 104: Strategies; International Organization for Standardization: Geneva, Switzerland, 2018.

39. ISO 10390. Soil Quality—Determination of pH.; International Organization for Standardization: Geneva, Switzerland, 2005.

40. Vorob'eva, L.A. Theory and Practice Chemical Analysis of Soils; GEOS: Moscow, Russia, 2006. (In Russian)

41. Shein, E.V. The particle-size distribution in soils. Problems of the methods of study, interpretation of the results, and classification. Eurasian Soil Sci. 2009, 42, 284-291. [CrossRef]

42. Fifield, F.W.; Haines, P.J. Environmental Analytical Chemistry; Blackie Academia \& Professional: London, UK, 1997.

43. Kubala-Kukus, A.; Banas, D.; Braziewicz, J.; Dziadowicz, M.; Kopec, E.; Majewska, U.; Mazurek, M.; Pajek, M.; Sobisz, M.; Stabrawa, I.; et al. X-ray spectrometry and X-ray microtomography techniques for soil and geological samples analysis. Nucl. Inst. Methods Phys. Res. B 2015, 364, 85-92. [CrossRef]

44. Håkanson, L. An ecological risk index for aquatic pollution control—A sedimentological approach. Water Resour. 1980, 14, 975-1001.

45. Nevidomskaya, D.; Minkina, T.; Fedorov, Y.; Kravtsova, N.; Litvinov, Y.; Nazarenko, O. Integral assessment of heavy metal pollution in Don River estuary soils. APEEM 2020, 169, 01007. [CrossRef]

46. Guidelines MU 21.7.730-99. Hygienic Evaluation of Soil in Residential Areas; Rospotrebnadzor: Moscow, Russia, 1999. (In Russian)

47. Du Laing, G.; Tack, F.M.G.; Verloo, M.G. Performance of selected destruction methods for the determination of heavy metals in reed plants (Phragmites australis). Anal. Chim. Acta 2003, 497, 191-198. [CrossRef]

48. Parengam, M.; Judprasong, K.; Srianujata, S.; Jittinandana, S.; Laoharojanaphand, S.; Busamongko, A. Study of nutrients and toxic minerals in rice and legumes by instrumental neutron activation analysis and graphite furnace atomic absorption spectrophotometry. J. Food Compos. Anal. 2010, 23, 340-345. [CrossRef]

49. Welz, B.M. SperlingAtomic Absorption Spectrometry, 3rd ed.; Wiley-VCH: Weinheim, Germany, 1999.

50. State Agroindustrial Committee of the USSR. Provisional Maximum Permissible Levels (MPL) for Some Chemical Elements and Gossypol in Forage for Farm Animals and Feed Additives; 123-4/281-8-87/State Agroindustrial Committee of the USSR; Main Directorate of Veterinary Medicine: Moscow, Russia, 1987. (In Russian)

51. Fedorov, A.A. Teratogenesis and Its Role in Plant Morfogenesis and Speciation. Species Problem in Botany; Publishing House of the USSR Academy of Sciences: Moscow, Russia, 1958. (In Russian)

52. Fedorenko, G.M.; Fedorenko, A.G.; Minkina, T.M.; Mandzhieva, S.S.; Sushkova, S.N.; Rajput, V.D.; Usatov, A.V. Method for hydrophytic plant sample preparation for light and electron microscopy (studies on Phragmites australis Cav.). Methods X 2018, 5 , 1213-1220. [CrossRef]

53. Vinogradov, F.P. Geochemistry of Rare and Dispersed Elements in Soils; AN SSSR: Moscow, Russia, 1957. (In Russian)

54. GN 21.7.2041. Maximum Permissible Concentrations (MPCs) of Chemical Substances in the Soil; Hygienic standards, Introduction: Moscow, Russia, 2006. (In Russian)

55. Akimtsev, V.V.; Boldyreva, A.V.; Golubev, S.N.; Kudryavtsev, M.I.; Rudenskaya, K.V.; Sadimenko, P.A.; Sobornikova, I.G. The contents of trace elements in soils of Rostov oblast. In Trace Elements and Natural Radioactivity of Soils; Rostovskii University: Rostov-on-Don, Russia, 1962; pp. 38-41. (In Russian)

56. Mohamed, B.A.; Huaxin, D. Effects of $\mathrm{Cr}, \mathrm{Cd}$, and $\mathrm{Pb}$ on Ultrastructure, GSH and Free Cysteine in Typha angustifolia. Transcriptomics 2015, 3, 115. [CrossRef]

57. Matishov, G.G.; Ivlieva, O.V.; Bespalova, L.A.; Kropyanko, L.V. Ecological and geographical analysis of the sea coast of the Rostov region. Dokl. Earth Sci. 2015, 460, 53-57. [CrossRef]

58. Ivlieva, O.V.; Bespalova, L.A.; Bespalova, E.V.; Kazachkova, E.M. Geoecological monitoring of the sea of Azov coastline (Rostov region). In Proceedings of the International Multidisciplinary Scientific GeoConference Surveying Geology and Mining Ecology Management, SGEM 17, Science and Technologies in Geology, Exploration and Mining, Albena, Bulgaria, 29 June-5 July 2017 ; International Multidisciplinary Scientific GeoConferences (SGEM): Sofia, Bulgaria, 2017; pp. 217-224.

59. Konstantinova, E.; Burachevskaya, M.; Mandzhieva, S.; Bauer, T.; Minkina, T.; Chaplygin, V.; Zamulina, I.; Konstantinov, A.; Sushkova, S. Geochemical transformation of soil cover and vegetation in a drained floodplain lake affected by long-term discharge of effluents from rayon industry plants, lower Don River Basin, Southern Russia. Environ. Geochem. Health 2020. [CrossRef]

60. Birch, G.F. Contaminated soil and sediments in a highly developed catchment-estuary system (Sydney estuary, Australia): An innovative storm water remediation strategy. J. Soils Sedim. 2011, 11, 194-208. [CrossRef]

61. Kasimov, N.; Shinkareva, G.; Lychagin, M.; Kosheleva, N.; Chalov, S.; Pashkina, M.; Thorslund, J.; Jarsjö, J. River Water Quality of the Selenga-Baikal Basin: Part I-Spatio-Temporal Patterns of Dissolved and Suspended Metals. Water 2010, 12, 2137. [CrossRef] 
62. Kasimov, N.; Shinkareva, G.; Lychagin, M.; Kosheleva, N.; Chalov, S.; Pashkina, M.; Thorslund, J.; Jarsjö, J. River Water Quality of the Selenga-Baikal Basin: Part II-Metal Partitioning under Different Hydroclimatic Conditions. Water 2020, 12, 2392. [CrossRef]

63. Rovira, A.; Ballinger, R.; Ibanez, C.; Parker, P.; Dominguez, M.D.; Lewandowski, X.S.A.; Hochfeld, B.; Tudor, M.; Vernaeve, L. Sediment imbalances and flooding risk in European deltas and estuaries. J. Soils Sedim. 2014, 14, 1439-1512. [CrossRef]

64. Sritrairat, S.; Peteet, D.M.; Kenna, T.C.; Sambrotto, R.; Kurdyla, D.; Guilderson, T. A history of vegetation, sediment and nutrient dynamics at Tivoli North Bay, Hudson Estuary, New York. Estuar. Coast Shelf. Sci. 2012, 102, 24-35. [CrossRef]

65. Romic, D.; Romic, M.; Zovko, M.; Bakic, H.; Ondrasek, G. Trace metals in the coastal soils developed from estuarine floodplain sediments in the Croatian Mediterranean region. Environ. Geochem. Health. 2012, 34, 399-416. [CrossRef]

66. Clemans, S. Molekular mechanisms of plant metal tolerance and homeostasis. Planta 2001, 212, 475-486. [CrossRef]

67. Salem, Z.B.; Laffray, X.; Ashoour, A.; Ayadi, H.; Aleya, L. Metal accumulation and distribution in the organs of Reeds and Cattails in a constructed treatment wetland (Etueffont, France). Ecol. Eng. 2014, 64, 1-17. [CrossRef]

68. Ratushnyak, A.Y.; Chakhirev, I.V.; Andreeva, M.G.; Trushin, M.V. Features of the formation of morphological structures and production of Typha angustifolia under load on lead. Biosci. Biotechnol. Res. Asia 2014, 11, 365-369. [CrossRef]

69. Maleva, M.G.; Borisova, G.G.; Shiryaev, G.I.; Kumar, A.; Morozova, M.V. Adaptive potential of Typha latifolia L. under extreme technogenic pollution. AIP Conf. Proc. 2019, 2063, 030013. [CrossRef] 